\title{
Absolutization of Political Power as an Anti-Thesis to Democracy: A Study of Select Novels of Benyamin
}

\author{
Nevisvanan $\mathrm{M}$ and Rajavelu $\mathrm{R}$ \\ Deapartment of English, Kanchi Mammunivar Government Institute \\ for Post Graduate Studies and Research, Puducherry, India
}

\begin{abstract}
The absolutization of power is dangerous and toxic. It is a threat to humanity whose chief characteristic is diversity, as it leads to the jeopardizing of the same. History has shown us how absoultism often challenged the existence of the other, marginalizing it and finally making it non-existent. When applied to political power, absolutization suffers from the very same defect. This paper seeks to show how Jasmine Days and Al Arabian Novel Factory explore the pre and post revolution scenario in the City of Joy. Both the novels are centered on 'His Majesty' who enjoys absolute power and silences the voices of dissent like that of the writers, activists, rebels and finally against his own people in the country. The absolute power of 'His Majesty' channelizes the various government organizations within his government to silence these voices- the essence of democracy.
\end{abstract}

\section{KEY WORDS: ABSOLUTISM, POLITICAL POWER, DEMOCRACY, VOICES OF DISSENT AND THE OTHER.}

\section{INTRODUCTION}

Conflict is inevitable when diverse groups of people live together. In order for these groups of people to thrive as a society and live in harmony, governance by law and order is a mandate. Humanity has witnessed different types of governments. A family or clan-based government is put forward by the evolutionary theory. Force theory talks about dictatorship rule and the divine right theory is all about monarchy. Finally, through long years of disappointments and failures emerged the democratic way of governance. It's based on the mutual understanding between the governing and the governed. The abovementioned types of governance have always posed a challenge to democracy. It shows how power if vested in one individual or in a powerful group will result in the misuse of the same. It can also be sometimes true to democracy if power is absolutized. The intrinsic problem in all of these categories is therefore the absolutization of power.

Biosc Biotech Res Comm P-ISSN: 0974-6455 E-ISSN: 2321-4007

\section{crossef}

Identifiers and Pagination

Year: 2021 Vol: 14 No (8) Special Issue

Pages: 29-32

This is an open access article under Creative

Commons License Attribn 4.0 Intl (CC-BY). DOI: $h t t p: / / d x$.doi.org/10.21786/bbrc/14.8.7

Benyamin, the author of the novels under consideration, Jasmine Days(JD) and Al Arabian Novel factory(AANF) lived in Bahrain for many years as a migrant worker. His novels explore the pre and post revolution scenario of an unknown middle east country from the perspective of two protagonists namely Sameera Parvin in Jasmine Days and Pratap in Al Arabian Novel Factory. The novels are centered on the ruler who is called as "His Majesty"( JD 81). He enjoys absolute power and silences the many voices of dissent. He channelizes his power through various government organizations. These novels reveal to us about how protests, dissent and revolution can unfold in the face of an authoritarian regime.

Jasmine Days presents the story of Sameera Parvin, a Pakistani who lands in the city to stay with her father and work in the Orange FM. Sameera understands the dynamics of power structure in the country where her uncles and father are part of the police force. Majority of the police force consist of people from Pakistan. While working in the Radio station she encounters people from diverse countries. Ali Fardhan, a native of the country expresses his opinion about the outsiders who live a first class life while the natives are treated as second class people by "His Majesty's"(JD 81) regime. The death of the innocent boy Jasim brings in a spark for revolution. People start to organize peaceful protest against the regime. The people throughout the country, especially the natives voiced their displeasure through their protest in

Article Information

Received: $09^{\text {th }}$ Apr 2021 ccepted after revision: $11^{\text {th }}$ June 2021 
the Pearl of Square. Sameera understands the background to the issue and inwardly she supports the protestors for their logical reasons towards the regime but outwardly she supports the regime.

The migrant population in the country are in support of "His Majesty"(JD 81) and show their solidarity towards him. This brings in a breach between Sameera and Ali's friendship and finally he is removed from the job because of his participation in the protest. The situation starts to worsen when the protestors become violent towards the police force. Sameera hears a news which shatters her. While controlling the protestors in the protest, her father was killed by a youth who drove the car mercilessly over him. Later Sameera comes to know that it was her friend from FM station, Ali who killed her father. She is in a state of shock because of her close friend murdering her father. Later "His Majesty" decides to give a huge settlement money with a demand that Sameera leave the country if she accepts the regime's settlement. When she is hesitant to accept it and decides to dissent against the regime, her uncle shows her the video of "His Majesty"( JD 81) attacking women who dissented against him.

The protestors in this protest are against the regime for equality and freedom and are not against the foreigners. A voice very prevalent within the protestors is that the foreigners have a high stake in the survival of the regime as it provides them with various economical and personal benefits. While the foreigners held a rally in support of "His Majesty"(81), the locals say, " Mr. Vulture came to power forty years ago and hasn't allowed any democratic process in all this time"(Jasmine Days 104). The protagonist Sameera requests Rajeevan to broadcast the real news about the protest that is happening in the country. She also says how she needs to stay on His Majesty's side in order to survive in the country but inwardly she wants the protestors to win. The locals resist against the move of the foreigners and tweet, "History will judge you" (JD 144). The revolutionaries claim that government and its agencies only publish one side of the stories that happens in support of the regime and avoid the voice of the locals.

When the protest is at the peak in the Pearl of Square, the ruler is busy dancing with the dancers of the neighboring country. Throughout the novel Sameera is held in a double state of confusion between the regime and protestors. "The protestors had finally broken down-they were now running away from the final fate that awaited them."(JD 190). Many a times people in power try to silence the voice and dilute history, exercising hegemony against civil society protest which happens against them. Pratap Bhanu Mehta in conversation with 'The Wire' with Karan Thapar, talks about the government's intolerance of those who disagree with it or oppose it thus, All that matters is the crushing of real and imaginary enemies, by hook or by crook. It encourages violence against anyone who is not in tune with it. The government annihilates our will, our reason, our spirit, so that we all become willing supplicants in its ideological project.
"His Majesties"(JD 81) regime decides to bring down the symbol of protest site, post revolution, being very cautious to erase the memories of protest, dissent and the revolution. Many foreigners in support of "His Majesty" claimed that the symbol of hatred and division will be brought down immediately referring to the protest site. What they fail to realize is that to erase a cultural symbol of protest is to only temporarily obliterate the memories of the revolution. To hide the truth and reality which is hidden from the outside world is an act of authoritarianism. Rightly did Mark Hauggard in his work Democracy, Political Power, and Authority comments that "Pure political power, devoid of violence and coercion, is a rare phenomenon " (1050). One question that haunts the mind of Sameera is how her father and her uncles in her family turn into acting agencies of the government in the field by attacking innocent women, children and men. She is confused by how power and authority when transmitted into bureaucracy, turn people to be violent predators.

Max Weber in his essay The Iron Age of Rationality says, "Bureaucracies may be difficult to destroy because they are created by society. It can also be changed by society" (The Sociology Book 43). The attitude of questioning in the society helps every institution to be responsible to its citizens. A relative of Ali, an old man who comes to talk with Sameera tries to explain the two different aspects of one situation, in the novel thus, Perhaps you didn't notice this. Up until that scene, your father was the attacking vulture and Ali was the hare but the moment your baba lost his gun he turned into a hare and Ali became the vulture (233). This indicates that people like "His Majesty's"(JD 81) orders are obeyed faithfully by his agencies which serve and satisfy all his needs.

Sameera feels that due to the polarized minds of her friend Ali towards extremist ideas and her father's being subservient to the orders of "His Majesty" (JD 81) she is being brought to experience such a pain. But her uncle explains towards the end of the story that "Certain decisions in the country cannot be questioned. Whether we see any rationale behind them or not we must obey them" ( JD 243). This indicates the argument of this paper that power can be absolutized by any individual. It can be a democratically elected leader, a Dictator or a Fascist, all alike control every action around them. Enforcing absolute power through the agencies towards people and controlling the actions of one's own people makes it very clear that democratic aspect of questioning is silenced in absolute power.

The second novel under study, Al Arabian Novel factory presents the story of Pratap, a Keralite-turnedCanadian-citizen working with Toronto Sunday. His boss James Hogan wants him to research on geography and sociology of the West Asian countries. Pratap chooses the nameless Arab country referred to as the City in order to meet his long-lost love Jasmine. His team comprises of four members from diverse countries. In the team Riyaz carries, an air of secrecy with him from the beginning. Pratap meets various people from his native Kerala 
especially Biju and Daisy. Their opinions about the regime are positive and they feel very happy to be part of the regime. It is the post revolution scenario, when the protagonist, Pratap, a journalist from Toranto Sunday, reaches the city which is still very much in turmoil. The protest has almost come to a standstill but the spirit of the revolution quite continues. There are several instances in the novel where atrocities are being carried out against individuals and groups.

A poet named Ayat who reads her political poem in the Pearl of Square is questioned and harassed by the police. The whole family is being traumatized for this act of hers. Her trial is conducted for seven months and she is sent to mental asylum. The judge expresses his opinion that writing poetry is a mental illness. This case, is another instance which exposes "His Majesty" who utilizes the bureaucracy to exercise absolute power to control every single act of the people. Pratap while meeting the locals of the country, gets to know their opinion about "His Majesty"(AANF 35). He comes to know how they live in absolute poverty and are treated as second class citizens.

The regime practices various methods of oppression against the common people. For example, it is a being brought to Pratap's cognizance how the regime purposefully allows the people to protest many times when it could have been actually controlled without escalating into violence. Pratap meets various activists, writers and radical members to understand the plight of the revolution. When once, he casually visits Riyaz's room, he comes across a book titled "A Silent Spring" "The story of a people whose lives were ground to dust by the wheels of authoritarianism" (AANF 69) by Sameera Parvin and gets hooked to the story. The story largely talks about the various happenings in the revolution.

One other authoritarian act of oppression by the regime is to restrict the public from reading. Alex Perumal, another character gets into trouble by bringing a book to read. It was suggested by a bookshop owner. This book is banned by the regime to be read and distributed. The act of reading is restricted by the regime because it will create a spark within the readers and impel the country towards revolution, which is a threat to the regime. Due to this restriction, the act of reading Sameera's banned book is kept secretive throughout the novel. Pratap meets a writer named Al Qaid who has been a part of the struggle against the British rulers. Pratap comes across such people who had dissented against the regime whose voices have forcefully turned silent in the years. Dr. Mamu is one such example. He shares with Pratap how he was locked in a room and prevented from treating the wounded policeman who was left to die by the regime. Through this one death of the policeman, "His Majesty" (AANF 35) ended the protest through his police and military force.

When British left the country, they invest all power to one family which was "His Majesty's" family. Al Qaid says that "we held elections and voted in parliament.
In his fifth year though, His Majesty's family declared an emergency and disbanded parliament" (52 AANF). Al Qaid opines that it's a surveillance state and that many within the country are spies for the regime. At the same time Pratap also identifies the spirit of revolution existing even in the post revolution scenario as he meets various writers and activists who were part of revolution at various times.

This shows that it is no rule that in an authoritarian regime that everything should be accepted when it is imposed upon the people. Disagreement with any kind of authority is personal and totally cannot be done away with it. This space for disagreement is found everywhere, explicitly in a democracy and implicitly in an authoritarian regime. Democracy need not be solely seen as a form of government but as the collective spirit of the people. Though "His Majesty" (35) employs absolute power in his governance the people still find numerous ways to react. Even in an authoritarian regime there is no written rule that people should not express their dissatisfaction and disappointments towards the government. The expression of these feelings is the spirit of democracy which could and can be seen in an authoritarian regime too. In his book Democracy 80 Questions and Answers, David Beethan and Kevin Boyle, says:

Conventionally we have come to call a state democratic if its government is accountable to the people. Through competitive election to public office, where all adults have an equal right to vote and to stand for election, and where civil and political rights are legally guaranteed (2). But does this mean an autocratic regime need not be accountable to people? In a democracy too there can be shades of autocracy. In an autocracy people can still possess the spirit of democracy which is the spirit of dissent and the spirit of disagreement. In any kind of government, the people are the center. Democracy should not be viewed as a mere form of government but as an attitude, perspective and as a point of view:

Democracy thus presupposes diversity and plurality within society as well as equality between citizens. And when such diversity finds expression, the democratic method of resolving difference in through discussion, through persuasion and compromise, rather than by forcible imposition or the simple assertion of power (4). The absence of any such mechanism in an autocratic regime makes matters complicated and leads to turmoil and revolution in a country. A mode of discussion and compromise if present, will end tyranny and massacre. The possibility of dialogue is absent in the regime and its agencies. Whether it is a democracy or an authoritarian regime where ever power is absolutized, it becomes a threat to the survival of the masses. Even though absolutization of power is an anti-thesis to democracy, it is very much possible in a democracy too. It is precisely why this paper attempts to view democracy not as a mere form of government but as a latent spirit of rebellion and dissent against the absolutization of power. Whether the masses desire it or not power always is absolutized 
in any form of government and whether those in power desire it or not people always will react against such absolutized power. Whether one of these is resolved or not, the presence of both is very much there. It coexists and will continue to exist.

\section{REFERENCES}

Beethan, David, and Kevin Boyle. Democracy: 80 Questions and Answers. National Book Trust of India with UNESCO, 1996, pp. 1-33.

Benyamin. Al Arabian Novel Factory. Translated by Shahnaz Habib, Juggernaut Books, 2019.

Benyamin. Jasmine Days. Translated by Shahnaz Habib, Juggernaut Books, 2018.

Gill, Harsiman. "Benyamin on Dissent, Democracy And Writing In An Age of Fear." Huffpost. 1 Apr. 2020, www. huffpost.com/archive/in/entry/benyamin-al-arabiannovel-factory-books_in_5e0f20e3c5b6b5a713b8c7b2.
Accessed 20 Mar. 2021.

Hamilton, Omar Robert. The City Always Wins. Faber and Faber, 2017, pp. 103-104.

Haugaard, Mark. "Democracy, Political Power, and Authority.” Social Research, vol. 77, no. 4, 2010, pp. 1049-1074. JSTOR, www.jstor.org/stable/23347119. Accessed 24 Mar. 2021.

Jose, Jinoy. "In conversation with Benyamin, the winner of the JCB Prize." The Hindu. 26 0ct. 2018, www. thehindu.com/books/benyamin-is-the-winner-of-thejcb-prize/article25331033.ece. Accessed 20 Mar. 2021. Mehta, Pratap Bhanu. "'Colloquially Speaking, BJP is Fascist. And More Insidious Than Indira's Emergency'| Karan Thapar ." The Wire , uploaded by The Wire, 29 Jan. 2020, www.youtube.com/ watch? $\mathrm{v}=5$ hiDcd2GiDA\&t $=1112 \mathrm{~s}$.

Weber, Max. The Sociology Book, The Iron Age of Rationality. Edited by Sam Atkinson. Dorling Kindersley Limited, 2015, pp. 40-45. 